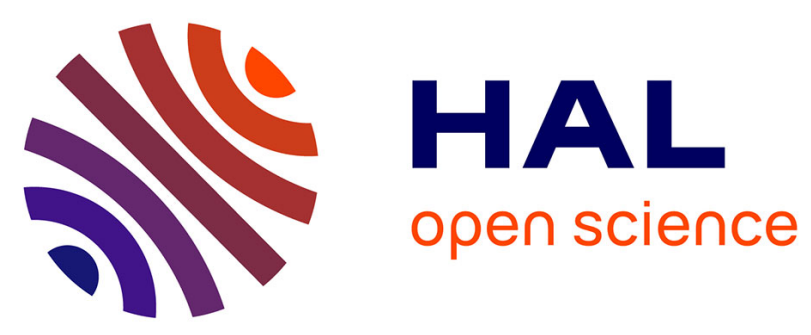

\title{
Is it possible to use expired tubes for routine biochemical analysis in dogs?
}

Margarida Canelas Domingos, Christine Medaille, Didier Concordet, Alexandra Briend-Marchal

\section{- To cite this version:}

Margarida Canelas Domingos, Christine Medaille, Didier Concordet, Alexandra Briend-Marchal. Is it possible to use expired tubes for routine biochemical analysis in dogs?. Veterinary Clinical Pathology, 2012, 41 (2), pp.266-271. 10.1111/j.1939-165X.2012.00424.x . hal-01191328

\section{HAL Id: hal-01191328 \\ https://hal.science/hal-01191328}

Submitted on 1 Sep 2015

HAL is a multi-disciplinary open access archive for the deposit and dissemination of scientific research documents, whether they are published or not. The documents may come from teaching and research institutions in France or abroad, or from public or private research centers.
L'archive ouverte pluridisciplinaire HAL, est destinée au dépôt et à la diffusion de documents scientifiques de niveau recherche, publiés ou non, émanant des établissements d'enseignement et de recherche français ou étrangers, des laboratoires publics ou privés. 
ORIGINAL RESEARCH

\title{
Is it possible to use expired tubes for routine biochemical analysis in dogs?
}

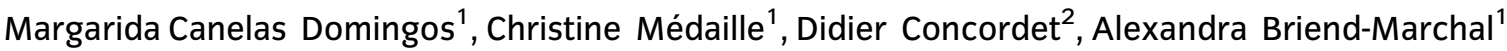 \\ ${ }^{1}$ Laboratoire Vebiotel, Arcueil, France and ${ }^{2}$ UMR 181 Physiopathologie et Toxicologie Expérimentales, INRA, Ecole Nationale Vétérinaire de Toulouse, \\ Toulouse, France
}

\author{
Key Words \\ Canine, clinical chemistry, expiration date, \\ heparin, plasma

\section{Correspondence} \\ Margarida Canelas Domingos, Laboratoire \\ Vebiotel, 41 bis Avenue Aristide Briand, 94117 \\ Arcueil, France \\ E-mail:margcdom@gmail.com
}

DOI:10.1111/j.1939-165X.2012.00424.x
Background: Expired collection tubes may be used inadvertently and resampling is not always possible. To date, studies have not been conducted in veterinary medicine to determine whether or not biochemical measurements obtained from specimens collected into expired tubes are accurate enough for clinical decision-making.

Objectives: The aims of this preliminary study were to assess the impact of measuring routine plasma biochemical analytes in canine specimens collected in expired tubes and to investigate the relationship between postexpiration time and the magnitude of errors.

Methods: Blood specimens were collected from 61 dogs and aliquoted equally into tubes containing lithium heparin and gel. One tube was within the expiration date, and the other tube was up to 11 months postexpiration. Plasma was separated within 1 hour of specimen collection, and concentrations of urea, creatinine, total protein, albumin, total bilirubin, cholesterol, triglycerides, magnesium, calcium, phosphates, sodium, potassium, chloride, total $\mathrm{CO}_{2}$, and fructosamine and activities of alanine aminotransferase, aspartate aminotransferase, alkaline phosphatase (ALP), $\gamma$-glutamyltransferase, lactate dehydrogenase, creatine kinase, amylase, and lipase were analyzed immediately and results compared.

Results: For most analytes there was no significant difference between results from specimens collected in non-expired and expired tubes. For ALP and lipase activities and fructosamine and total $\mathrm{CO}_{2}$ concentrations, significant differences were found, and results obtained for fructosamine and total $\mathrm{CO}_{2}$ from specimens in expired tubes may have led to erroneous interpretations. The effect of time since expiration was constant over time. Conclusions: When specimens are processed within 1 hour of collection, results of routine biochemical measurements of blood collected in lithium heparin tubes remain clinically valid for up to 11 months after expiration of tubes for the majority of analytes, except for ALP, lipase, fructosamine, and total $\mathrm{CO}_{2}$.

\section{Introduction}

In human medicine, the most common causes of variation in laboratory medicine occur during the preanalytical phase, ${ }^{1}$ and it is likely that this is also true for veterinary medicine. Errors may occur at any time from specimen collection to submission to the laboratory to processing of the specimen by the laboratory. ${ }^{2}$ In veterinary medicine, the preanalytical phase is controlled primarily by the clinician or veterinary techni- cian, who should ensure that all preanalytical procedures are standardized and conducted in accordance with laboratory requirements.

Commercial collection tubes, especially tubes containing anticoagulants such as heparin, EDTA, or citrate, have expiration dates to ensure they are suitable for use and to maintain desired quality. Expiration dates, an important quality control factor, may not be checked prior to specimen collection, and it is not unusual for a laboratory to receive specimens in expired 
tubes. It is not always possible to collect another specimen, and, thus, it is important to know the impact of using expired tubes on laboratory results. In a study of ethanol measurement in human medicine, use of tubes that had expired up to 74 months prior to specimen collection had no impact on results. ${ }^{3}$ Although many studies in veterinary medicine have reported the influence of storage time, temperature, repeated freeze-thaw cycles, and different anticoagulants on plasma analytes, ${ }^{4-8}$ to our knowledge a study of the effect of using expired tubes has not been reported.

In this preliminary study, we chose to limit our investigation to the use of heparin-lithium tubes with gel separator for biochemical analysis of plasma. Plasma is often preferred to serum for routine biochemical analysis; it can be obtained more quickly, as there is no need to wait for clot formation and centrifugation velocity can be increased, and a larger volume is obtainable, which is particularly important for specimens from small animals. ${ }^{9}$ In addition, anticoagulation prevents formation of small clots that may interfere with analysis. ${ }^{9}$ Finally, the risk of hemolysis and lysis of platelets is reduced. ${ }^{9}$ The purpose of this preliminary study was to assess the impact of measuring routine plasma biochemical analytes in canine specimens collected in expired tubes and to investigate the relationship between post-expiration time and the magnitude of errors.

\section{Materials and Methods}

The study was conducted from November 2009 to September 2010, and the only inclusion criterion was the availability of sufficient blood volume to fill 2 tubes equally from a single collection of blood from dogs presented to a local veterinary hospital (Fregis, Arcueil, France). Blood was collected uniformly, in a volume of 2.5-3 mL per tube, into $23.5-\mathrm{mL}$ tubes containing lithium heparin and gel (Venosafe, VF-054SAHL; Terumo Europe NV, Leuven, Belgium). One tube was within the expiration date, and the other tube had expired by $2,4,6,7,8$, or 11 months.

Specimens were transported to the Vebiotel Laboratory, located minutes away from the veterinary hospital. To separate plasma from cellular elements, tubes

Table 1. Methods, imprecision, and values for canine plasma analytes measured in blood collected in non-expired tubes containing lithium heparin and gel.

\begin{tabular}{|c|c|c|c|}
\hline Analyte & Method & $\begin{array}{l}\text { Imprecision } \\
\text { CV (\%) }\end{array}$ & $\begin{array}{l}\text { Median values } \\
\text { (minimum/maximum) }\end{array}$ \\
\hline Urea g/L & Enzymatic assay (urease; $37^{\circ} \mathrm{C}$ ) & 5.05 & $0.3(<0.07 / 7.3)$ \\
\hline Creatinine $\mathrm{mg} / \mathrm{L}$ & Kinetic Jaffé reaction (alkaline picrate solution; $37^{\circ} \mathrm{C}$ ) & 4.27 & $7(5 / 206)$ \\
\hline Total Protein g/L & Biuret assay (cupric ions; $37^{\circ} \mathrm{C}$ ) & 6.47 & $58(37 / 78)$ \\
\hline Albumin $g / L$ & Bromcresol Green $\left(37^{\circ} \mathrm{C}\right)$ & 2.44 & $29(23 / 36)$ \\
\hline Total Bilirubin mg/L & Modified Diazo reaction (p-nitrobenzenediazonium salt; $37^{\circ} \mathrm{C}$ ) & 8.47 & $2(1 / 51)$ \\
\hline Cholesterol g/L & Enzymatic assay (cholesterol esterase and cholesterol oxidase; $37^{\circ} \mathrm{C}$ ) & 7.74 & $2.4(0.9 / 5.7)$ \\
\hline Triglycerides g/L & Enzymatic assay (lipase, glycerokinase, glycerol-3-phosphateoxidase; $37^{\circ} \mathrm{C}$ ) & 5.67 & $0.5(0.2 / 2.4)$ \\
\hline ALT U/L & Enzymatic assay (substrates: L-alanine and 2-oxoglutarate; $37^{\circ} \mathrm{C}$ ) & 6.98 & $60(15 / 1215)$ \\
\hline AST U/L & Enzymatic assay (substrates: L-aspartate and 2-oxoglutarate; $37^{\circ} \mathrm{C}$ ) & 5.64 & $27(<2 / 505)$ \\
\hline ALP U/L & Enzymatic assay (substrate: p-nitrophenylphosphate; $37^{\circ} \mathrm{C}$ ) & 6.69 & $66(11 / 5377)$ \\
\hline GGT U/L & Enzymatic assay (substrates: L- $\gamma$-glutamyl-3-carboxy-4-nitroanilide and glycylglycine; $37^{\circ} \mathrm{C}$ ) & 7.03 & $5(<7 / 146)$ \\
\hline Amylase U/L & Enzymatic assay (substrate: ethylidene-pNP-G7; $37^{\circ} \mathrm{C}$ ) & 8.28 & $721(251 / 4315)$ \\
\hline Lipase U/L & $\begin{array}{l}\text { Enzymatic assay (substrate: } 1.2-0 \text {-dylauryl-rac-glycero-3-glutaric } \\
\left.\text { acid-(6-methylresorufin) ester; } 37^{\circ} \mathrm{C}\right)\end{array}$ & 9.21 & $79(12 / 3668)$ \\
\hline Creatine Kinase U/L & Enzymatic assay (substrates: creatine phosphate and ADP; $37^{\circ} \mathrm{C}$ ) & 5.86 & $154(39 / 5449)$ \\
\hline $\mathrm{LDH} U / \mathrm{L}$ & Enzymatic assay (substrates: L-alanine and NAD; $37^{\circ} \mathrm{C}$ ) & 4.59 & $66(19 / 302)$ \\
\hline Fructosamine $\mu \mathrm{mol} / \mathrm{L}$ & Colorimetric assay (nitrotetrazolium blue; $37^{\circ} \mathrm{C}$ ) & 6.39 & $259(169 / 394)$ \\
\hline Magnesium mg/L & Colorimetric assay (sodium salt of xylidyl blue I; $37^{\circ} \mathrm{C}$ ) & 5.34 & $16(9 / 28)$ \\
\hline Calcium mg/L & Colorimetric assay (arsenazo III dye; $37^{\circ} \mathrm{C}$ ) & 4.20 & $103(77 / 119)$ \\
\hline Phosphates mg/L & Colorimetric assay (ammonium molybdate; $37^{\circ} \mathrm{C}$ ) & 4.20 & $40(22 / 196)$ \\
\hline Sodium $\mathrm{mmol} / \mathrm{L}$ & ISE direct potentiometry $\left(22^{\circ} \mathrm{C}\right)$ & 3.78 & $146(130 / 160)$ \\
\hline Potassium mmol/L & ISE direct potentiometry $\left(22^{\circ} \mathrm{C}\right)$ & 3.01 & $3.9(3.3 / 5.2)$ \\
\hline Chloride $\mathrm{mmol} / \mathrm{L}$ & ISE direct potentiometry $\left(22^{\circ} \mathrm{C}\right)$ & 4.54 & $107(78 / 135)$ \\
\hline Total $\mathrm{CO}_{2} \mathrm{mmol} / \mathrm{L}$ & Enzymatic assay (substrate: phosphoenolpyruvate carboxylase; $37^{\circ} \mathrm{C}$ ) & 8.60 & $24(13 / 39)$ \\
\hline
\end{tabular}


were centrifuged (Heraeus Megafuge 16 centrifuge; Thermo Scientific, Osterode, Germany) within 1 hour of specimen collection at $1500 \mathrm{~g}$, room temperature (average $22^{\circ} \mathrm{C}$ ), for 6 minutes. Plasma color was inspected for hemolysis, lipemia, or icterus; if preset, specimens were excluded to avoid interference with the biochemical assays. Analyses of 23 analytes were performed immediately after plasma separation using a Konelab 20i chemistry analyzer (Thermo Scientific) with defined methods and performance (Table 1). Quality control was monitored 2-3 times per week (up to 50 analyses between control runs) using normal, high, or low control material (Konelab, Cergy Pontoise, France) depending on the analyte.

\section{Statistical analysis}

Differences between the logarithm of concentrations or activities obtained from specimens collected in expired and non-expired tubes were computed and analyzed using a linear model that included a constant with time post-expiration as a fixed factor; the expiration factor accounted for a non-constant effect of time of expiration on the measured concentrations or activities. When this factor was not significant, the nullity (value equal to 0) of the constant was investigated using a Fisher's test. The exponential function of this constant was the median variation expressed as a percentage of the concentrations or activities obtained from specimens collected in expired vs non-expired tubes. Significance was set at $P<.05$.

\section{Results}

Blood specimens were collected from 61 dogs of various age (6 months to 16 years), sex (male or female), disease status (healthy or sick), and state of consciousness (anesthetized or awake). Specimens were collected from $11,8,8,10,12$, and 12 dogs into tubes that had expired by $2,4,6,7,8$, and 11 months, respectively, and into non-expired tubes. Plasma specimens had no visible hemolysis, lipemia, or icterus. Total $\mathrm{CO}_{2}$ concentration was not measured in the first 7 dogs owing to insufficient reagent.

For the majority of analytes, results from specimens collected in expired and non-expired tubes did not differ significantly (Table 2). Activities of alkaline

Table 2. Differences in values for canine plasma biochemical analytes between specimens collected into non-expired and expired tubes.

\begin{tabular}{|c|c|c|c|c|c|c|c|}
\hline \multirow[b]{2}{*}{ Months after expiration $(n *)$} & \multicolumn{6}{|c|}{ Median (maximum/minimum) percent difference } & \multirow[b]{2}{*}{$P$} \\
\hline & 2 months (11) & 4 months (8) & 6 months (8) & 7 months (10) & 8 months (12) & 11 months (12) & \\
\hline Creatinine & $0(14 /-3)$ & $0(11 /-40)$ & $0(14 / 0)$ & $0(14 /-13)$ & $0(20 /-14)$ & $0(14 /-17)$ & NS \\
\hline Total Protein & $0(5 /-4)$ & $-1(8 /-24)$ & $-1(6 /-6)$ & $-2(5 /-10)$ & $-1(7 /-7)$ & $-2(3 /-9)$ & NS \\
\hline Albumin & $-3(8 /-12)$ & $-3(17 /-38)$ & $0(6 /-4)$ & $-1(10 /-9)$ & $0(4 /-3)$ & $-2(4 /-7)$ & NS \\
\hline Cholesterol & $0(10 /-15)$ & $0(25 /-14)$ & $0(4 /-8)$ & $0(7 /-7)$ & $0(12 /-25)$ & $0(11 /-20)$ & NS \\
\hline Triglycerides & $0(11 /-20)$ & $0(25 /-50)$ & $0(17 / 0)$ & $0(0 /-25)$ & $0(20 /-33)$ & $0(20 /-8)$ & NS \\
\hline $\mathrm{ALT}$ & $0(2 /-21)$ & $0(6 / 0)$ & $0(5 /-6)$ & $-1(3 /-7)$ & $0(4 /-4)$ & $0(12 /-5)$ & NS \\
\hline AST & $-1(11 /-11)$ & $0(50 /-12)$ & $0(5 /-16)$ & $-1(92 /-27)$ & $-1(9 /-11)$ & $-7(8 /-52)$ & NS \\
\hline ALP & $1(2 /-6)$ & $0(7 /-5)$ & $0(8 /-2)$ & $0(6 /-3)$ & $0(8 /-4)$ & $1(18 /-7)$ & .039 \\
\hline GGT & $0(25 /-50)$ & $-20(25 /-150)$ & $20(100 /-17)$ & $5(100 /-200)$ & $18(50 /-50)$ & $13(125 /-7)$ & NS \\
\hline Lipase & $-2(4 /-10)$ & $-10(3 /-53)$ & $1(4 /-8)$ & $-3(13 /-14)$ & $-3(15 /-25)$ & $-4(19 /-100)$ & .027 \\
\hline Creatine Kinase & $2(22 /-7)$ & $0(12 /-10)$ & $-2(12 /-16)$ & $-4(10 /-52)$ & $0(11 /-14)$ & $-3(13 /-56)$ & NS \\
\hline $\mathrm{LDH}$ & $9(36 /-3)$ & $6(70 /-7)$ & $-2(47 /-55)$ & $0(17 /-57)$ & $0(18 /-40)$ & $-3(82 /-133)$ & NS \\
\hline Fructosamine & $0(4 /-2)$ & $3(8 /-3)$ & $0(19 /-3)$ & $2(13 /-5)$ & $2(6 /-18)$ & $2(11 /-7)$ & .032 \\
\hline Magnesium & $-7(6 /-15)$ & $0(6 /-13)$ & $0(13 /-11)$ & $0(12 /-5)$ & $-3(8 /-13)$ & $0(14 /-25)$ & NS \\
\hline Calcium & $4(7 /-4)$ & $-2(3 /-12)$ & $1(15 /-8)$ & $0(2 /-1)$ & $0(11 /-7)$ & $0(8 /-4)$ & NS \\
\hline Phosphates & $0(7 /-4)$ & $-2(3 /-26)$ & $0(3 /-7)$ & $-1(9 /-38)$ & $0(7 /-44)$ & $0(40 /-8)$ & NS \\
\hline Sodium & $0(1 / 0)$ & $0(1 /-1)$ & $0(1 /-1)$ & $0(1 / 0)$ & $0(1 /-1)$ & $0(1 /-1)$ & NS \\
\hline Potassium & $0(7 /-8)$ & $0(2 /-3)$ & $0(3 /-3)$ & $0(3 /-3)$ & $1(3 /-11)$ & $0(3 /-3)$ & NS \\
\hline Chloride & $0(1 /-1)$ & $0(2 /-1)$ & $0(1 /-1)$ & $0(1 /-1)$ & $0(0 /-2)$ & $0(1 /-1)$ & NS \\
\hline Total $\mathrm{CO}_{2}$ & $0(0 /-9)$ & $0(4 /-8)$ & $4(12 /-6)$ & $0(5 /-24)$ & $-4(4 /-53)$ & $-3(5 /-15)$ & .032 \\
\hline
\end{tabular}

$*_{n}$ indicates number of specimens compared, except for total $\mathrm{CO}_{2}$ for which $n=4,8,8,10,12$, and 12 for $2,4,6,7,8,11$ months, respectively. ALP, alkaline phosphatase; ALT alanine aminotransferase; AST, aspartate aminotransferase; GGT; $\gamma$-glutamyl transferase; LDH, lactate dehydrogenase; NS, not significant. 
phosphatase (ALP) and lipase and concentrations of fructosamine and total $\mathrm{CO}_{2}$ were significantly different $(P=.039, .027, .032$, and .032 , respectively) between the two tubes. The effect of using expired tubes on ALP and lipase activities and fructosamine and total $\mathrm{CO}_{2}$ concentrations was not significantly different for different times post-expiration (Figure 1), and the median variations of (non-expired-expired)/non-expired were $1.3,-4.5,1.7$, and $-2.6 \%$, respectively. On close inspection of differences, 3 differences (Figures 1B and 1D) could have be considered as outliers according to Tukey's criterion of \pm 3 interquartile range: 2 for lipase activity (4 and 11 months post-expiration) and 1 for total $\mathrm{CO}_{2}$ concentration (8 months post-expiration).
Other than the use of expired tubes, analytical or preanalytical conditions could not be found to account for these differences. If these values were excluded, then the corresponding relative median differences were 2.1 and $0.0 \%$, for lipase activity and total $\mathrm{CO}_{2}$ concentration, respectively.

For ALP and lipase activities and fructosamine and total $\mathrm{CO}_{2}$ concentrations, the largest difference was usually found when dogs had values within the reference intervals established by the laboratory (based on measurements of specimens collected in non-expired tubes) with the exception of total $\mathrm{CO}_{2}$. In these circumstances, differences were $18 \%$ (11 U/L) for ALP at, $-100 \%(15 \mathrm{U} / \mathrm{L})$ for lipase, $19 \%(299 \mu \mathrm{mol} / \mathrm{L})$ for
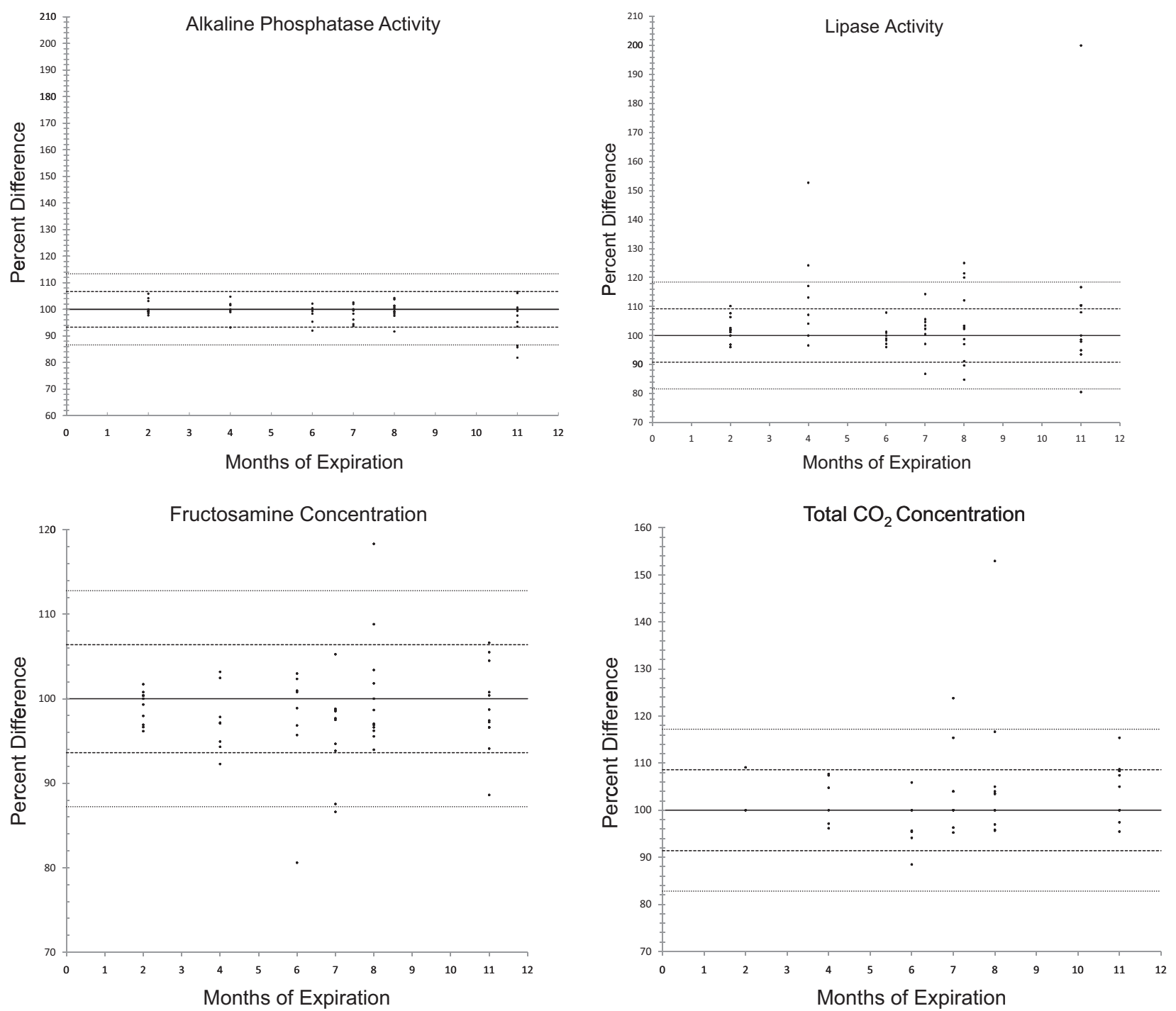

Figure 1. Individual proportional differences (\%) between measurements obtained from specimens collected in non-expired and expired tubes containing lithium heparin and gel. Only analytes for which significant differences were found are shown. Dotted lines represent \pm 1 and 2 SDs (expressed as coefficients of variation [\%]). 
Table 3. Differences in values for canine plasma analytes between specimens collected into non-expired and expired tubes when values for 4 analytes were outside the reference interval.

\begin{tabular}{lcccc}
\hline Analyte & \multicolumn{1}{c}{$\begin{array}{c}\text { Median (minimum/maximum) } \\
\text { percent difference }\end{array}$} & Minimum value & Maximum value & Reference interval \\
\hline ALP U/L & 21 & $0(-4 / 2)$ & 116 & 5377 \\
Lipase U/L & 8 & $-1(-6 / 5)$ & 424 & 360 \\
Fructosamine $\mu \mathrm{mol} / \mathrm{L}$ & 33 & $2(-5 / 8)$ & 169 & 394 \\
Total CO2 $\mathrm{mmol} / \mathrm{L}$ & 25 & $0(-53 / 12)$ & 13 & 390 \\
\hline
\end{tabular}

*Number of dogs with values outside reference interval.

ALP, alkaline phosphatase.

fructosamine, and $-53 \%(17 \mathrm{mmol} / \mathrm{L})$ for total $\mathrm{CO}_{2}$ (Tables 2 and 3). Differences $>2$ coefficient of variation of the respective method were 14\% (at 22 and $56 \mathrm{U} / \mathrm{L}$ ) and $18 \%$ (at $11 \mathrm{U} / \mathrm{L}$ ) for ALP activity; $-100 \%$ (at $15 \mathrm{U} / \mathrm{L}$ ), $-53 \%$ (at $93 \mathrm{U} / \mathrm{L}$ ), $-25 \%$ (at $20 \mathrm{U} / \mathrm{L}$ ), $-24 \%$ (at $62 \mathrm{U} / \mathrm{L}),-21 \%$ (at $42 \mathrm{U} / \mathrm{L}$ ), $-20 \%$ (at $70 \mathrm{U} / \mathrm{L}$ ), and $19 \%$ (at $159 \mathrm{U} / \mathrm{L}$ ) for lipase activity; $-18 \%$ (at $262 \mu \mathrm{mol} / \mathrm{L}$ ), $13 \%$ (at $336 \mu \mathrm{mol} / \mathrm{L}$ ), and $19 \%$ (at $299 \mu \mathrm{mol} / \mathrm{L}$ ) for fructosamine concentration; and $-53 \%$ (at $17 \mathrm{mmol} / \mathrm{L}$ ) and $-24 \%$ (at $21 \mathrm{mmol} / \mathrm{L}$ ) for total $\mathrm{CO}_{2}$ concentration.

\section{Discussion}

For most analytes, accurately measurements could be obtained when specimens were collected into lithium heparin/gel tubes that were up to 11 months postexpiration, and measurement of the majority of the analytes in specimens collected into expired tubes did not change the classification of results in comparing them with reference intervals. Although significant differences were found for ALP and lipase activities and fructosamine and total $\mathrm{CO}_{2}$ concentrations, differences did not increase with increasing time postexpiration and percent differences were low in most cases. For fructosamine and $\mathrm{CO}_{2}$, however, observed differences may have lead to misclassification of the result and possible erroneous interpretations. The clinical relevance of the observed differences is difficult to assess. The only objective criterion may be the critical difference, which, unfortunately, has only been determined in dogs for urea, creatinine, total protein, albumin, glucose, and cholesterol concentrations and ALP, ALT, AST activities and which varied from $7.9 \%$ to $46.7 \% .^{10}$

The lack of differences found in this study may not be applicable to specimens processed $>1$ hour after collection. A study of analysis of specimens stored for varying times in expired tubes and comparison with the reported 3-day stability of analytes in heparinized plasma (chloride and total $\mathrm{CO}_{2}$ not included $)^{11}$ might be useful. If expired tubes are used inadvertently, processing and analysis of specimens within 1 hour are recommended. Additional studies are needed with larger numbers of specimens to evaluate possible effects on other analytes, wider ranges of values, collection into other anticoagulants, and other species.

\section{Acknowledgments}

The authors would like to thank Dr. Doroteia Bota and nurses Carole Bouchet and Claudie Berriet from the Fregis Veterinary Hospital, Arcueil, France for providing the specimens for this study.

Disclosure: The authors have indicated that they have no affiliations or financial involvement with any organization or entity with a financial interest in, or in financial competition with, the subject matter or materials discussed in this article.

\section{References}

1. Bonini P, Plebani M, Ceriotti F, Rubboli F. Errors in laboratory medicine. Clin Chem. 2002;48:691-698.

2. Plebani M. Errors in clinical laboratories or errors in laboratory medicine? Clin Chem Lab Med. 2006;44:750759.

3. Zittel DB, Hardin GG. Comparison of blood ethanol concentrations in samples simultaneously collected into expired and unexpired venipuncture tubes. J Anal Toxicol. 2006;30:317-318.

4. Saunier V, Lombard E, Ducros C, et al. Etude de conservation des échantillons sanguins avant analyse [Study of the effects of blood specimen storage before analysis]. Feuillets de Biologie. 2009;L(291):41.

5. Rendle DI, Heller J, Hughes KJ, Innocent GT, Durham AE. Stability of common biochemistry analytes in equine blood stored at room temperature. Equine Vet $J$. 2009;41:428-432.

6. Cray C, Rodriguez M, Zaias J, Altman NH. Effects of storage temperature and time on clinical biochemical 
parameters from rat serum. J Am Assoc Lab Anim Sci. 2009;48:202-204.

7. Reynolds B, Taillade B, Medaille C, Palenché F, Trumel C, Lefebvre HP. Effect of repeated freeze-thaw cycles on routine plasma biochemical constituents in canine plasma. Vet Clin Pathol. 2006;35:339-340.

8. Céron JJ, Martínez-Subiela S, Hennemann C, Tecles F. The effects of different anticoagulants on routine canine plasma biochemistry. Vet J. 2004; 167:294-301.

9. Desch G, Duchassaing D, Eloy O, et al. Analyses de biochemie [Biochemical analysis]. In: Ghnassia JC, ed.
Echantillons Biologiques: Phase Préanalytique et Prélèvements en Biologie Médicale [Biological Samples: Pre-Analytical Phase and Samples in Medical Biology]. 1st ed. Paris, France: Elsevier; 1998:22-23.

10. Jensen AL, Aaes H. Critical differences of clinical chemical parameters in blood from dogs. Res Vet Sci. 1993;54: 10-14.

11. Thoresen SI, Havre GN, Morberg H, Mowinckel P. Effects of storage time on chemistry results from canine whole blood, heparinized whole blood, serum and heparinized plasma. Vet Clin Pathol. 1992;21:88-94. 